\title{
Materials on the distribution of plant species which are rare for the Volgograd oblast
}

\author{
Stepan Senator ${ }^{*}$, Vladimir Vasjukov ${ }^{1}$, Eugene Zibzeev ${ }^{2}$, and Andrey Korolyuk ${ }^{2}$ \\ ${ }^{1}$ Institute of Ecology of the Volga river basin of RAS, 445003, Komzina Str., 10, Togliatti, Russia \\ ${ }^{2}$ Central Siberian Botanical Garden, SB RAS, 630090, Zolotodolinskaja Str., 101, Novosibirsk, Rus- \\ sia
}

\begin{abstract}
The information about the distribution of 28 rare and endangered species of vascular plants under Federal and regional security, registered in 2018 on the territory of the Volgograd oblast under the Federal and regional security is given. Among them, 2 species (Crambe tataria Sebeók и Stipa zalesskii Wilensky ex P. A. Smirn.) are included in the List of Threatened plant species of Europe. Each location is linked to the grid of Atlas Flora Europaea. The obtained materials about the distribution of rare and endangered species of vascular plants represent an important data for long-term monitoring and also for environmental management measures at the regional level.
\end{abstract}

\section{Introduction}

Volgograd oblast is located in the South-East of the European part of Russia in the basins of the Lower Volga and the Middle Don. The majority of this region belongs to the steppe zone. Zonal vegetation is herb-bunchgrass (moderately arid) and bunchgrass (dry) steppes, which are now replaced by half-shrub-bunchgrass desert steppe to the East and South-East. Only small area in the North-West belongs to the forest-steppe zone.

This region has high, unique for lowlands vascular plant diversity: more than 2970 species were registered there [1]. In this regard, information on the distribution of rare and threatened with extinction species is valuable from a scientific and environmental point of view. The present work provides new information, specifying the distribution of some vascular plants under the protection at the regional and Federal levels.

\section{Materials and methods}

Field studies were implemented May 22-31, 2018 in the Volga region and the Middle Don. It is the territory of the Frolovsky, Gorodishchensky, Ilovlinsky, Kalachevsky, Leninsky, Nikolaevsky and Pallasovsky districts of the Volgograd oblast.

The following sources were used for determining the species: "Flora of the Lower Volga region" [2, 3], "Conspectus florae Europae Orientalis" [4], "Flora of a central part of the European Russia" [5].

* Corresponding author: stsenator@yandex.ru 
The nomenclature and volume of taxa are mainly standardized by "The Euro+Med PlantBase" [6]. Abbreviations of taxa authors are given according to "International Plant Name Index" [7].

The geographical coordinates are given in WGS 84 system when quoting labels. The number of the square is indicated in brackets in Atlas Flora Europaea [8]. Collected herbarium specimens are stored in PVB; doublets are transferred to MW and NS.

\section{Results}

The studies revealed 565 species of vascular plants [9], 19 species of which are included in the Red Book of the Russian Federation [10], 28 species are in the Red Book of Volgograd oblast [1] and 2 species are in the List of European Red List of Vascular Plants [11].

Data on findings of rare vascular plants are presented below. Collection of vascular plants and the species inside are listed in order of the Latin alphabet. * - species listed in the Red Book of the Russian Federation [10].

\section{Asteraceae}

Artemisia salsoloides Willd.*: 1) 4902'54" N, 4333'07" E, Kalachevsky dist., northern surroundings of the Evlampievsky farmstead, the upper parts of the Bolshaja Golubaja river, marl-chalk outcrops, 28.V.2018 [38ULV4]; 2) 49¹0'59" N, 4345'15" E, Ilovlinsky dist., Natural park "Donskoy", right bank of the Don river, marl-chalk outcrops, 29.V.2018 [38UMV2].

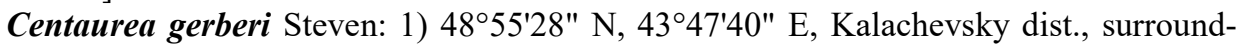
ings of the Peskovatka village, sands on the left bank of the Don river, 25.V.2018 [38UMV2].

Jacobaea schwetzowii (Korsh.) Tatanov et Vasjukov [Senecio schwetzowii Korsh.]: 1) $49^{\circ} 02^{\prime} 44^{\prime \prime} \mathrm{N}, 43^{\circ} 32^{\prime} 47^{\prime \prime} \mathrm{E}$, Kalachevsky dist., northern surroundings of the Evlampievsky farmstead, the upper parts of the Bolshaja Golubaja river, forb-grass meadows in the floodplain, 27.V.2018 [38ULV4].

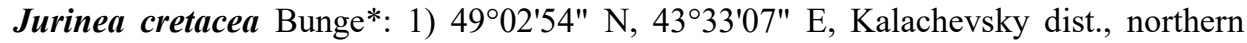
surroundings of the Evlampievsky farmstead, the upper parts of the Bolshaja Golubaja

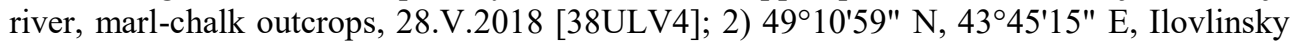
dist., Natural park "Donskoy", right bank of the Don river, marl-chalk outcrops, 29.V.2018 [38UMV2].

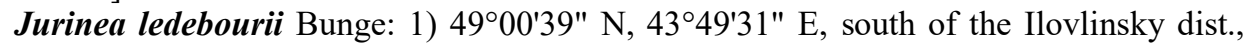
right bank of the Don river, feather-grass steppe with forbs, 29.V.2018 [38UMV2].

\section{Brassicaceae}

Crambe tataria Sebeók: 1) 4902'54" N, 4333'07" E, Kalachevsky dist., northern surroundings of the Evlampievsky farmstead, the upper parts of the Bolshaja Golubaja river, marl-chalk outcrops, 28.V.2018 [38ULV4]. Listed in the European Red List of vascular plants, category LC [11].

Lepidium coronopifolium Fisch. ex DC.: 1) 5007'23" N, 46 $19^{\prime} 25^{\prime \prime}$ E, Nikolaevsky dist., surroundings of the Libnekht village, to the south-west of the sheep barn "Kulturnaja", dry steppe dominated by Festuca valesiaca, Stipa lessingiana, and Tanacetum achilleifolium, 22.V.2018 [38UNA3].

Lepidium meyeri Claus*: 1) 4902'54" N, 4333'07" E, Kalachevsky dist., northern surroundings of the Evlampievsky farmstead, the upper parts of the Bolshaja Golubaja river, marl-chalk outcrops, 28.V.2018 [38ULV4]; 2) 49¹0'59" N, 4345'15" E, Ilovlinsky dist., Natural park "Donskoy", right bank of the Don river, marl-chalk outcrops, 29.V.2018 [38UMV2].

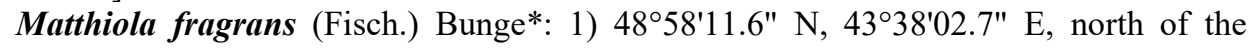
Kalachevsky district, left bank of the Bolshaja Golubaja river, chalk outcrops, 29.V.2018 


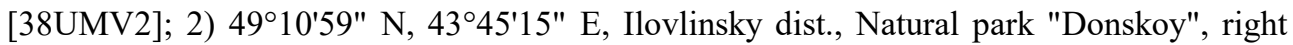
bank of the Don river, marl-chalk outcrops, 30.V.2018 [38UMV2].

\section{Caryophyllaceae}

Otites hellmannii (Claus) Stankov [Silene hellmannii Claus]*: 1) 4902'54" N, $43^{\circ} 33^{\prime} 07^{\prime \prime}$ E, Kalachevsky dist., northern surroundings of the Evlampievsky farmstead, the upper parts of the Bolshaja Golubaja river, marl-chalk outcrops, 28.V.2018 [38ULV4]; 2) $49^{\circ} 10^{\prime} 59^{\prime \prime} \mathrm{N}, 43^{\circ} 45^{\prime} 15^{\prime}$ E, Ilovlinsky dist., Natural park "Donskoy", right bank of the Don river, marl-chalk outcrops, 30.V.2018 [38UMV2].

\section{Colchicaceae}

Colchicum laetum Steven*: 1) 4902'54" N, 43³3'07" E, Kalachevsky dist., northern surroundings of the Evlampievsky farmstead, the upper parts of the Bolshaja Golubaja river, feather-grass steppe with forbs, 28.V.2018 [38ULV4].

\section{Cupressaceae}

Juniperus sabina L.: 1) $49^{\circ} 11^{\prime} 24.5^{\prime \prime} \mathrm{N}, 43^{\circ} 36^{\prime} 04.4^{\prime \prime}$ E, Ilovlinsky dist., surroundings of the Sirotinskaja village, chalk outcrops, 30.V.2018 [38ULV4]; 2) 49²7'57" N, 4341'14" E, Ilovlinsky dist., surroundings of the Viltov village, Archedinsko-Donskie sands, 30.V.2018 [38UMV1]; 3) 49³0'11" N, 4338'46" E, Frolovsky dist., surroundings of the Zimovsky village, Archedinsko-Donskie sands, 31.V.2018 [38UMV1].

\section{Fabaceae}

Genista tanaitica P. A. Smirn.*: 1) 4902'54" N, 4333'07" E, Kalachevsky dist., northern surroundings of the Evlampievsky farmstead, the upper parts of the Bolshaja Golubaja river, marl-chalk outcrops, 28.V.2018 [38ULV4]; 2) 49¹0'59" N, 4345'15" E, Ilovlinsky dist., Natural park "Donskoy", right bank of the Don river, marl-chalk outcrops, 29-30.V.2018 [38UMV2].

Hedysarum cretaceum DC.*: 1) 48 58'11.6" N, 4338'02.7" E, north of Kalachevsky dist., left bank of the Bolshaja Golubaja river, chalk outcrops, 29.V.2018 [38UMV2]; 2) $49^{\circ} 10^{\prime} 59^{\prime \prime} \mathrm{N}, 43^{\circ} 45^{\prime} 15^{\prime \prime} \mathrm{E}$, Ilovlinsky dist., Natural park "Donskoy", right bank of the Don river, marl-chalk outcrops, 30.V.2018 [38UMV2].

Hedysarum smirnovii Knjasev: 1) 4902'54" N, 43³3'07" E, Kalachevsky dist., northern surroundings of the Evlampievsky farmstead, the upper parts of Bolshaja Golubaja river, marl-chalk outcrops, 28.V.2018 [38ULV4]; 2) 49¹0'59" N, 4345'15" E, Ilovlinsky dist., Natural park "Donskoy", right bank of the Don river, marl-chalk outcrops, 29.V.2018 [38UMV2]; 3) 49 $11^{\prime} 24.5^{\prime \prime} \mathrm{N}, 43^{\circ} 36^{\prime} 04.4^{\prime \prime} \mathrm{E}$, Ilovlinsky dist., surroundings of the Sirotinskaja village, chalk outcrops, 30.V.2018 [38ULV4].

Note. Hybridogenic species derived from hybridization H. biebersteinii Chrtková $\times$ $H$. grandiflorum Pall. It is recommended for inclusion in the new edition of the Red Book of Volgograd oblast.

\section{Iridaceae}

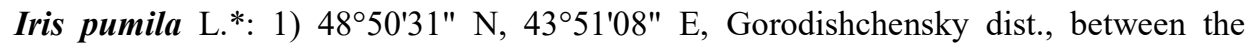
Peskovatka and Dmitrievka villages, forb and feather-grass steppe in the Rubezhnaja balka, 27.V.2018 [38UMV2]; 2) 4902'44" N, 4332'47" E, Kalachevsky dist., northern surroundings of the Evlampievsky farmstead, the upper parts of the Bolshaja Golubaja river, feathergrass steppe with forbs, 27.V.2018 [38ULV4].

\section{Lamiaceae}

Hyssopus cretaceus Dub.*: 1) 4902'54" N, 4333'07" E, Kalachevsky dist., northern surroundings of the Evlampievsky farmstead, the upper parts of the Bolshaja Golubaja river, marl-chalk outcrops, 28.V.2018 [38ULV4].

\section{Liliaceae}

Fritillaria ruthenica Wikstr.*: 1) 5007'23" N, 46²19'25" E, Nikolaevsky dist., surroundings of the Libnekht village, to the south-west of the sheep barn "Kulturnaja", dry steppe dominated by Festuca valesiaca, Stipa lessingiana, and Tanacetum achilleifolium on 
moistened microdepressions along the Rybnaja Soljanka river, 22.V.2018 [38UNA3]; 2) $49^{\circ} 00^{\prime} 39^{\prime \prime} \mathrm{N}, 43^{\circ} 49^{\prime} 31^{\prime \prime} \mathrm{E}$, south of Ilovlinsky dist., right bank of the Don river, oak and maple bairak forest, 29.V.2018 [38UMV2].

Tulipa schrenkii Regel [T. gesneriana auct. non L.]*: 1) 5007'23" N, 46²19'25" E, Nikolaevsky dist., surroundings of the Libnekht village, to the south-west of the sheep barn "Kulturnaja", dry steppe dominated by Festuca valesiaca, Stipa lessingiana, and Tanacetum achilleifolium, 22.V.2018; 2) 49²5'17" N, 4601'00" E, Pallasovsky dist., north-west surroundings of the Bulukhta lake, Yudina stow, herb-bunchgrass steppe with Tanacetum achilleifolium and forb-grass steppe with Artemisia lerchiana, 23.V.2018 [38UNV3]; 3) $48^{\circ} 41^{\prime} 58^{\prime \prime} \mathrm{N}, 45^{\circ} 31^{\prime} 56^{\prime \prime} \mathrm{E}$, Leninsky dist., $3 \mathrm{~km}$ to the north of the Kolobovka village, desert steppe, 24.V.2018 [38UNU1].

\section{Poaceae}

Koeleria sclerophylla P. A. Smirn.*: 1) 4902'54" N, 4333'07" E, Kalachevsky dist., northern surroundings of the Evlampievsky farmstead, the upper parts of Bolshaja Golubaja river, marl-chalk outcrops, 28.V.2018 [38ULV4].

Stipa cretacea P. A. Smirn.: 1) 4902'54" N, 4333'07" E, Kalachevsky dist., northern surroundings of the Evlampievsky farmstead, the upper parts of the Bolshaja Golubaja

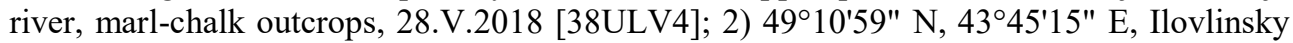
dist., Natural park "Donskoy", right bank of the Don river, marl-chalk outcrops, 29.V.2018

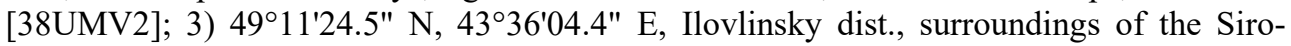
tinskaja village, chalk outcrops, 30.V.2018 [38ULV4].

Stipa dasyphylla (Czern. ex Lindem.) Trautv.*: 1) 4900'39" N, 4349'31" E, south of the Ilovlinsky dist., right bank of the Don river, feather-grass steppe with forbs, 29.V.2018 [38UMV2].

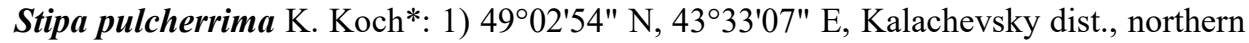
surroundings of the Evlampievsky farmstead, the upper parts of the Bolshaja Golubaja riv-

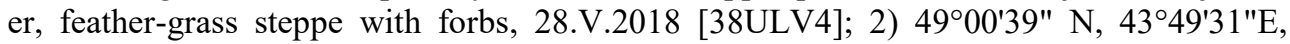
south of the Ilovlinsky dist., right bank of the Don river, feather-grass steppe with forbs,

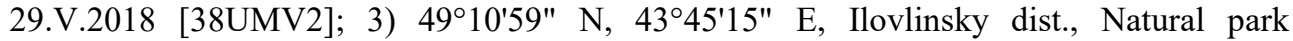
"Donskoy", right bank of the Don river, forb-grass communities with Artemisia lerchiana, 29.V.2018 [38UMV2].

Stipa zalesskii Wilensky ex P. A. Smirn.*: 1) 5007'23" N, 46²19'25" E, Nikolaevsky dist., surroundings of the Libnekht village, to the south-west of the sheep barn "Kulturnaja", dry steppe dominated by Festuca valesiaca, Stipa lessingiana, and Tanacetum achilleifolium, 22.V.2018 [38UNA3]; 2) 4902'54" N, 4333'07" E, Kalachevsky dist., northern surroundings of the Evlampievsky farmstead, the upper parts of Bolshaja Golubaja river, feather-grass steppe with forbs, 28.V.2018 [38ULV4]. Listed in the European Red List of vascular plants, category DD [11].

\section{Ranunculaceae}

Delphinium puniceum Pall.*: 1) 4902'44" N, 43³2'47" E, Kalachevsky dist., northern surroundings of the Evlampievsky farmstead, the upper parts of the Bolshaja Golubaja river, feather-grass steppe with forbs, 27.V.2018 [38ULV4].

Pulsatilla pratensis Mill.*: 1) 49³0'11" N, 4338'46" E, Frolovsky dist., surroundings of the Zimovsky village, Archedinsko-Donskie sands, 31.V.2018 [38UMV1].

\section{Rubiaceae}

Asperula tephrocarpa Popov et Chrshan.: 1) 4902'54" N, 4333'07" E, Kalachevsky dist., northern surroundings of the Evlampievsky farmstead, the upper parts of Bolshaja Golubaja river, marl-chalk outcrops, 28.V.2018 [38ULV4].

\section{Scrophularaceae}

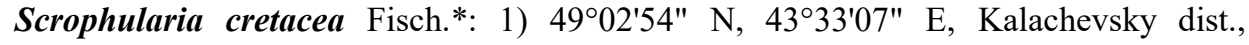
northern surroundings of the Evlampievsky farmstead, the upper parts of the Bolshaja Go- 
lubaja river, marl-chalk outcrops, 28.V.2018 [38ULV4]; 2) 49¹0'59" N, 4345'15" E, Ilovlinsky dist., Natural park "Donskoy", right bank of the Don river, marl-chalk outcrops, 29.V.2018 [38UMV2].

\section{Discussion}

As a result of the research, 13 localities of 28 species of vascular plants, listed in the Red Book of Volgograd oblast [1] were identified, 19 species of which are included in the Red Book of the Russian Federation [10] and 2 species are in the European Red List of vascular plants [11]. Most of the detected species is confined in its distribution to the chalk and marl-chalk outcrops. Each location is linked to the grid of Atlas Flora Europaea.

The obtained materials on the distribution of rare and threatened species of vascular plants are the important data for long-term monitoring, as well as for environmental measures at the regional level.

\section{Acknowledgements}

The work was carried out in the framework of the state task of Institute of Ecology of the Volga river basin of the RAS, theme № 0128-2014-0002.

\section{References}

1. The Red Book of Volgograd oblast. Plants and other organisms, 2 (Volgograd, Publisher-Printer, 2017)

2. Flora of the Lower Volga region, 1 (Moscow, KMK Sci. Publ., 2006)

3. Flora of the Lower Volga region, 2 (Moscow, KMK Sci. Publ., 2018)

4. Conspectus florae Europae Orientalis, 1 (Moscow; Saint-Petersbourg, 2012)

5. P.F. Maevskij, Flora of a central part of the European Russia, 11th ed. (Moscow, 2014)

6. Euro+Med (2006): Euro+Med PlantBase - the information resource for EuroMediterranean plant diversity. Published on the Internet http://ww2.bgbm.org/EuroPlusMed/ [accessed 18 July 2019].

7. The International Plant Names Index (2019). Published on the Internet http://www.ipni.org [accessed 18 July 2019]

8. Grids and mapping - Atlas florae Europaeae. https://www.luomus.fi/ [accessed 18 July 2019]

9. S.A. Senator, V.M. Vasjukov, E.G. Zibzeev, A.Y. Korolyuk, S.V. Saksonov, Phytodiversity of Eastern Europe, XII, 4 (2018)

10. The Red Book of the Russian Federation (plants and fungi) (Moscow, KMK Sci. Press, 2008

11. M. Bilz, S.P. Kell, N. Maxted, R.V. Lansdown, European Red List of Vascular Plants (Luxembourg, Publications Office of the European Union, 2011) 